Bond University

Research Repository

\title{
The Impact of non Interest Income on Bank Risk in Australia
}

\author{
Williams, Barry
}

Licence:

CC BY-NC-ND

Link to output in Bond University research repository.

Recommended citation(APA):

Williams, B. (2012). The Impact of non Interest Income on Bank Risk in Australia. Poster session presented at Research Week 2012, Gold Coast, Queensland, Australia.

\section{General rights}

Copyright and moral rights for the publications made accessible in the public portal are retained by the authors and/or other copyright owners and it is a condition of accessing publications that users recognise and abide by the legal requirements associated with these rights.

For more information, or if you believe that this document breaches copyright, please contact the Bond University research repository coordinator. 


\section{BOND UNIVERSITY}

FACULTY OF BUSINESS

\section{Research Question}

How has bank income diversification impacted upon bank risk?

\section{Background}

The last two decades has seen bank revenue evolve away from the 'traditional

intermediation model' towards increased income from non interest income.

\section{What are the benefits of this study?}

\$ Provides more information about the factors impacting upon bank risk.

\$ Banks are under increased scrutiny post GFC and increased regulation; these debates should be informed by facts.

All Banks Revenue Composition

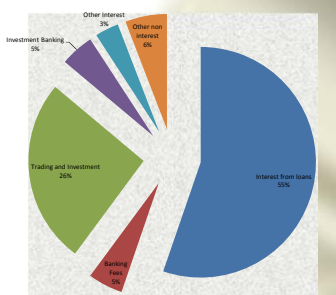

Bank fees on deposit and loan accounts are only a small proportion of total revenue

Interest Income is still the most important

\section{The impact of non interest income on bank risk in}

Barry Williams, School of Business, Bond University, Globalisation and Development Center, Bond University.

What is new about this study?

No Australian evidence to date.

$\$$ Applies data drawn from the confidential quarterly return provided by all Australian bank to the Australian

Prudential regulation Authority (APRA).

These data has not been analysed by external researchers.

Applies new measure of bank revenue risk.

\section{OAPRA}

Research Design and Method.

Data covers 2002 to 2008

All banks in Australia.

Feasible GLS estimation to control for

\section{Model Design}

$\$$ Four measures of bank risk (i) volatility of Return on assets, (ii) volatility of return on equity (iii) distance to default (z score) (iv) distance to breach of capital regulations (regulatory z score)

$\$$ Volatility measured using range based variables (log [high value - low value]) $\$$ Controls for portfolio composition, size and bank type.

$\$$ Break revenue into six categories determine which contribute to bank risk or risk reduction.

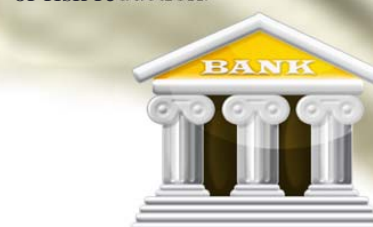

\section{Australia} Visiting Researcher, KOF Institute, ETH Zurich.

First stage results:

\$ Does revenue diversification reduce bank risk?

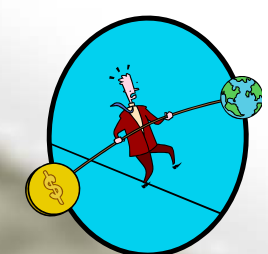

Overall results

Trading and investment revenue reduce bank risk.

Decreasing returns to scale in risk reduction \$ Bigger banks are less risky, but only up to a point, the major banks are most likely beyond that point. (This applies ONLY to risk reduction and scale.)

$\$$ Model does not work as well for distance to default (z score) measure.

\$ Australian banks are well-capitalized and so the marginal impact of revenue changes on risk are small.

\$ Specialisation is risk reducing but non interest income is riskier than traditional revenue.

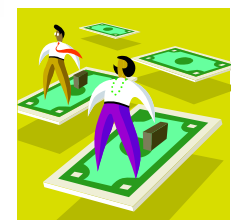

\section{Answer:}

$$
\$ \text { NO }
$$

\$ Increased revenue concentration associated with lower risk

Second stage Res Which components of increase or decrease hank risk?

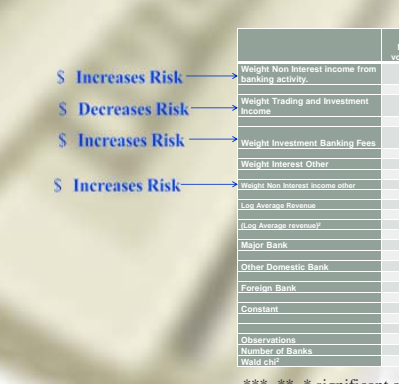

\section{Implications}

\section{$\$$ Bank revenue composition is important in} determining bank risk.

\$ Non interest income (except for Trading and Investment income) is risk increasing.

\$ Australian banks are well capitalised and marginal changes in revenue composition

\$ Choosing banks for peer analysis should

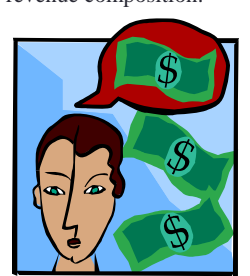

